\title{
Poesia, imagem e teoria: ressonâncias escatológicas a partir de Casaldáliga, Cerezo e Westhelle
}

\section{Jefferson Zeferino}

Pontifícia Universidade Católica do Paraná

\section{Marcio Luiz Fernandes}

Pontifícia Universidade Católica do Paraná

Ana Beatriz Dias Pinto

Pontifícia Universidade Católica do Paraná

\section{Resumo}

Dom Pedro Casaldáliga traduziu em poesia seu itinerário como bispo, missionário e teólogo engajado na luta contra as várias injustiças que testemunhou. O presente texto objetiva relacionar sua poesia com a imagética de seu confrade claretiano Maximino Cerezo Barredo, bem como perceber, a partir das reflexões escatológicas do teólogo e pastor luterano Vítor Westhelle, a teologia da cruz que subjaz sua obra. Como resultado, apresenta-se uma escatologia espacial-martirial como transfundo das produções teológicas desses autores.

Palavras-chave: Teologia Pública. Teologia da Libertação. Escatologia espacial. Martírio. Poesia Latino-Americana.

\section{Poetry, imagery and theory: escathological ressonances stemming from Casaldáliga, Cerezo and Westhelle}

\begin{abstract}
Dom Pedro Casaldáliga translated into poetry his path as bishop, missionary and theologian who was engaged with the struggle against the many injustices he testified. The present text aims at relating his poetry with Maximino Cerezo Barredo's imagery, his Claretian confrere, and, based on the eschatological reflections of the Lutheran pastor and theologian Vítor Westhelle, noticing the theology of the cross that underlies his work. As a result, this work demonstrates a spacial-martirial eschatology in the background of these author's theological works.
\end{abstract}

Keywords: Public Theology. Liberation Theology. Spacial Eschatology. Martyrdom. Latin-American Poetry. 


\section{Poesía, imagen y teoría: resonancias escatológicas de Casaldáliga, Cerezo y Westhelle}

\section{Resumen}

Dom Pedro Casaldáliga tradujo en poesía su itinerario como obispo, misionero y teólogo comprometido en la lucha contra las diferentes injusticias de las que fue testigo. Este texto pretende relacionar su poesía con el arte pictórico de su hermano claretiano Maximino Cerezo Barredo, así como comprender, a partir de las reflexiones escatológicas del teólogo y pastor luterano Vítor Westhelle, la teología de la cruz que subyace a su obra. Como resultado, se presenta una escatología espacial-martirial como trasfondo de las producciones teológicas de esos autores.

Palabras clave: Teología Pública. Teología de la Liberación. Escatología especial. Martirio. Poesía Latinoamericana.

A cruz faz brotar atos de ressurreição

o reino de Deus

Dedicamos esse haicai e o texto a seguir à memória de Vítor Westhelle e de

Dom Pedro Casaldáliga que nos deixaram recentemente.

\section{Introdução}

A América Latina continua sangrando. Eventos recentes como a pandemia da Covid-19 evidenciaram mais uma vez as profundas injustiças sociais que constituem nosso continente. Se por um momento se teve a impressão de que a doença não fazia distinção de classe, deixando enlutadas famílias com realidades econômicas bastante distintas, logo se notou também que o acesso à higiene, água potável, educação sanitária, atendimento de saúde, possibilidade de trabalho remoto, não necessitando enfrentar aglomerações em transportes coletivos etc., faz muita diferença. Os espaços são determinantes nas chances de vida e de qualidade de vida. O Brasil, um dos países com maior número de mortes causadas pela pandemia, está acompanhado por um logo histórico de dores e lutas. Em 1968, num dos períodos mais duros do regime militar, chegava no Mato Grosso o missionário claretiano Pedro Casaldáliga. Alguém que desenvolve sua carreira encarnando em sua pele, pastoral e poesia a terra e a gente brasileira. Ele vê diante de si as cercas dos latifúndios, as margens do Araguaia, as fronteiras institucionais, os limites entre diferentes culturas, o sofrimento das pessoas marginalizadas e invisibilizadas, o martírio de tantas... tantos... 
Não é exagero dizer que é o próprio sangue dos mártires que une teologias do norte e do sul global. Em um prefácio à uma das edições de seu clássico Der Gekreuzigte Gott (O Deus Crucificado), após ter sido informado de que um exemplar de sua obra fora encontrado mergulhado no sangue dos padres jesuítas assassinados em El Salvador, Moltmann escreve o seguinte:

Encontrei a positiva influência de minha teologia da cruz especialmente na cristologia de Jon Sobrino, que a aprofundou e aguçou para o contexto latinoamericano. Aprendi de sua teologia da cruz, a qual ele não apenas ensinou, mas também sofreu. Alguns dias atrás recebi uma carta de Robert McAfee Brown, na qual ele me contou acerca desta comovente história ocorrida em San Salvador. Em 16 de novembro de 1989, seis reconhecidos jesuítas, juntamente com a empregada doméstica e sua filha, foram brutalmente assassinados na universidade local. O reitor da universidade, Padre Ignacio Ellacuría, foi um deles. Jon Sobrino escapou do massacre apenas porque aconteceu de ele não estar no país no momento. A carta continua, "Quando os assassinos arrastavam alguns corpos para dentro do prédio, enquanto levavam um dos corpos para dentro do quarto de Jon, acertaram uma estante e derrubaram um livro no chão, que ficou ensopado com o sangue do mártir [Juan Ramón Moreno]. Pela manhã, quando ajuntaram o livro, eles perceberam que se tratava do seu O Deus crucificado". Este sinal e símbolo me dá muito o que pensar. $\mathrm{O}$ que isto me diz é que estes mártires são a semente da ressurreição de um novo mundo. Assim como o Arcebispo Oscar Romero, eles são a esperança das pessoas: inesquecíveis, inextinguíveis, irresistíveis ${ }^{1}$ (MOLTMANN, 1993, p. xi-xii, tradução própria).

\footnotetext{
No original: "I found the positive influence of my theology of the cross especially in the Christology of Jon Sobrino, who deepened and sharpened it for the Latin American context. I have learnt from his theology of the cross, which he not only taught but suffered. A few days ago I received a letter from Robert McAfee Brown, in which he told me the following moving story from San Salvador. On 16 November 1989, six well-known Jesuits, together with their housekeeper and her daughter, were brutally murdered in the university there. The rector of the university, Father Ignacio Ellacuría, was one of them. Jon Sobrino escaped the massacre only because he happened not to be in the country at the time. The letter continues, 'When the killers were dragging some of the bodies back into the building, as they took one of the bodies into Jon's room, they hit a bookcase and knocked a book on to the floor, which became drenched with the martyr's blood. In the morning, when they picked up the book, they found that it was your The Crucified God.' This sign and symbol gives me a great deal to think about. What it says to me is that these martyrs are the seed of the resurrection of a new world. Like Archbishop Oscar Romero, they are the hope of the people: unforgettable, inextinguishable, irresistible" (MOLTMANN, 1993, p. xi-xii).
} 
O martírio (testemunho), para Moltmann, é semente de ressurreição para um novo mundo, um novo espaço, um novo tempo. Neste artigo, objetiva-se demonstrar justamente que esta força de sentido está presente na teopoética de Dom Pedro Casaldáliga (1928-2020), na arte mural de Cerezo Barredo (1932-) e na teologia de Vítor Westhelle (1952-2018). Como resultado, percebe-se um movimento de retroalimentação entre os símbolos da cruz e da ressurreição, em que práticas de ressurreição, encontrar vida em meio ao sofrimento, emergem do compromisso e do cuidado com o(s) crucificado $(\mathrm{s})^{2}$.

$\mathrm{Na}$ primeira parte apresentamos a relação entre Casaldáliga, Cerezo e Westhelle. Suas produções teológicas acontecem com os pés no chão, sentindo os sofrimentos dos espaços que habitaram. Em especial, atentase para a questão da luta pela terra como elemento comum que recebe contornos escatológicos. Na segunda parte, a partir da proposição westhelliana de compreender a relação entre cruz e ressurreição pela chave revelaçãoabscondicidade, analisa-se o mural do Santuário dos Mártires da Caminhada ${ }^{3}$ de Cerezo, a poesia explicativa ao mural feita por Casaldáliga e a poesia América Latina, também de Casaldáliga, que estampa uma das páginas da edição de agosto de 1992 da Revista Ave Maria junto a um recorte em imagem do referido mural. À guisa de conclusão sintetiza-se o caminho poético-imagético-teológico com a percepção de uma escatologia espacialmartirial que entende as obras dos três autores como práticas de ressurreição engajadas nas lutas sociais, além de evidenciar o nexo entre espaço e martírio como traduzido no jogo de palavras de Casaldáliga em que, num movimento

2 Neste sentido, vale os comentários de Mendonza-Álvarez sobre a afirmação de Vattimo de que a comunidade cristã pós-moderna precisa aprender a dar testemunho do Logos kenótico para de novo encontrar seu protagonismo na sociedade contemporânea. Trata-se de uma posição profética, mas inspirada em uma espiritualidade encarnada. Vale citar o que diz o teólogo mexicano: "A memória viva do Crucificado se encontra associada aos crucificados da história, como compreendeu e atestou o martírio de Ignacio Ellacuría. Essa anamnese nos permite entrar na lógica da kénosis, para nos situarmos no coração da história de dominação e de violência, a fim de vislumbrar aí os sinais do Reino de Deus entre os pobres e excluídos para anunciar a Parúsia” (MENDONZA-ÁLVAREZ, 2011, p. 156).

3 A construção do Santuário dos Mártires da Caminhada, em Ribeirão Bonito na Prelazia de São Félix do Araguaia-MT, constitui-se como um santuário-lugar, um espaço de humanização e lugar para sonhar a utopia. A cada ano ali se realiza uma romaria popular, em comemoração ao aniversário do martírio do padre João Bosco Penido Burnier. Nas palavras de Pedro Casaldáliga: "Essas romarias, participadas por muitos companheiros e companheiras da mesma Esperança, de muitos países da Nossa América e do Mundo, avivam a memória martirial e reacendem o compromisso militante: Vidas pela vida, vidas pelo Reino, vidas pelo Reino da vida" (CASALDÁLIGA, 2006, p. 31). 
teológico de revelação e ocultamento em que o exposto revela seu oposto, já a cruz alçada pelos algozes políticos e religiosos é erguida contra eles, o instrumento do martírio se torna símbolo de resistência e ressurreição.

\section{Casaldáliga, Cerezo e Westhelle: teologia e lutas sociais}

É significativo que o missionário claretiano catalão, Dom Pedro Casaldáliga, se notabilize como um teopoeta ${ }^{4}$ da libertação em língua portuguesa. Isso pode ser considerado um reflexo do espírito pós-conciliar de inculturação, mas também retrata a personalidade de alguém que ao chegar ao Brasil percebeu a necessidade de fixar moradia para que sua comunicação com aquele povo fosse efetiva, além de afetiva. Um companheiro dessa sua luta e caminhada foi aquele a quem denominou de pintor da libertação, Maximino Cerezo Barredo 5 .

Em entrevista à Arcelina Dias (2014), Pedro revela que ao chegar à Prelazia encontravam-se claramente distintos o mundo dos poderosos e o mundo dos pobres e que não existia a possibilidade de negação de uma tomada de decisão. Destaca o papel da comunicação em sua missão, tanto a comunicação com o povo, quanto à comunicação com os de fora, tornando pública a situação que lá encontravam. Os murais de Cerezo se inscrevem nessa tarefa de comunicação interna, como uma Biblia pauperum. Outro veículo que reúne Cerezo e Casaldáliga é o Alvorada, jornal da Prelazia, que possui

4 A teopoética é uma forma de se pensar teologicamente que, não raro, configura-se como tradução daquilo que se compreende como o mistério, o sagrado, Deus, em literaturas. Para além das abstrações e dos sistemas, apresenta-se como outro modo teológico de pensar a questão humana na atualidade. Isto pode ser desdobrado tanto na percepção da presença da teologia em formas literárias, como na possibilidade de análise teológica da literatura. (cf. VILLAS BOAS, 2011, p. 44-47). Na presente abordagem, ao se falar numa teopoética de Casaldáliga, compreende-se que há uma teologia presente em suas poesias. Além disso, com o auxílio de Westhelle, oferece-se uma interpretação teológica da teopoética de Casaldáliga e da imagética de Cerezo.

O pintor, sacerdote e missionário da Congregação Claretiana Maximino Cerezo Barredo nasceu em 4 de agosto de 1932 na cidade de Villaviciosa, na província das Astúrias, na Espanha. A vocação missionária e artística são as suas duas paixões que marcam a trajetória de sua vida. Em 1968, em uma viagem aos povoados das missões das Filipinas, Cerezo teve seu primeiro contato com as realidades dos países do Sul do mundo. Saiu de lá intencionado em deixar de lado a pintura e a arte, pois as considerava associadas a um estilo de vida burguês e distante da realidade dos mais pobres. No Brasil, sua atuação foi marcada pela colaboração com o bispo Pedro Casaldáliga, também ele claretiano, na Prelazia de São Félix do Araguaia. 
várias ilustrações de Barredo e se dedica a contar a vida daquela gente ${ }^{6}$. A autora menciona ainda o arquivo e a biblioteca do Centro Comunitário Tia Irene que dão base à proposta comunicacional da Prelazia (DIAS, 2014).

Cerezo Barredo, que havia conhecido Pedro Casaldáliga como jovem sacerdote na Espanha e colaborado como missionários na editoração da Iris, Revista de Testimonio y Esperanza de propriedade dos Missionários Claretianos, retrata a importância de se realizar um trabalho pastoral firmemente calcado no contexto sociocultural (DIAS, 2014). Cerezo explica assim o uso de suas imagens:

Estas imagens - desenhos, pinturas e espaços - surgem de uma práxis que, como aconselhava o bispo mártir argentino Enrique Angeleli (assassinado pela ditadura argentina em 1976), conseguiu ter olhar e ouvidos colocados simultaneamente no evangelho e no povo. Assim, estas imagens participam do que os teólogos latino-americanos denominam "uma reflexão crítica da práxis histórica à luz da Palavra de Deus”. É ato segundo do compromisso libertador cristão. Leonardo Boff, apresentando o livro Murais da Libertação - que recolhe meus trabalhos murais na Prelazia de São Felix do Araguaia fala da Teologia da Libertação como uma revolução espiritual em que tudo, de certa forma, assume uma nova configuração (CEREZO, 2015, p. 282)

É neste espírito de luta por libertação de uma gente sofrida que a parceria entre Casaldáliga e Cerezo toma forma. Entre os espaços que concretizaram a fusão de suas poesias e imagens está a Revista Ave Maria. Na mais tradicional revista mariana brasileira, o editor responsável, nos anos de 1990, apresentará, com frequência, uma poesia de Casaldáliga associada a uma imagem das obras pictóricas de Cerezo na contra-capa da Revista. Aliás, os dois estarão envolvidos em atividades de colaboração com a Editora AveMaria tanto na ilustração dos três ciclos da liturgia quanto na elaboração da Agenda Latino-Americana que terá ampla difusão nos ambientes políticos, culturais, sociais e eclesiais da América latina. Sabemos que ambos beberam profundamente na renovada eclesiologia de comunhão proposta pelo Vaticano II - exposta na Constituição Dogmática Lumen Gentium - e nas conclusões da II Conferência episcopal de Medellín que recepciona e interpreta o Concílio.

6 Na mesma entrevista, ao falar da relação com outras igrejas, destaca o bom relacionamento com os luteranos. Além de indicar a importância ecumênica da Comissão Pastoral da Terra (CPT) e do Conselho Indigenista Missionário (CIMI) (DIAS, 2014). Cabe destacar que o teólogo e pastor luterano Vítor Westhelle atuou junto à CPT no Paraná. 
A Revista Ave-Maria foi criada em 1898 por um grupo de leigos católicos que acompanhavam a construção do Santuário do Imaculado Coração de Maria, no bairro de Santa Cecília, em São Paulo (SP). A revista começou como um periódico de apenas quatro páginas e tiragem de 300 exemplares, com o propósito de ser um veículo de massa dedicado ao tema mariano e devocional. Um ano após o lançamento de sua primeira edição, sua direção ficou a cargo da Congregação dos Missionários Claretianos, que a mantém em circulação ininterrupta há 122 anos. Ao longo de todo esse período, trataram de difundi-la, ampliá-la e adequá-la à realidade pela qual diversas vezes o jornalismo de revista passou no Brasil e na América Latina $^{7}$. Logo após o Concílio Vaticano II vê-se uma completa mudança na perspectiva editorial. Pouco a pouco se vê realizar-se a transformação para uma visão editorial renovada, passando de uma linguagem devocionalapologética para uma linguagem mais teológico-catequética e pastoral. Mas serão mesmo decisivas as décadas de 1980 e 1990, na qual a revista adota uma direção editorial em plena consonância com a teologia produzida na América Latina, sendo um veículo para a defesa dos mais vulneráveis e excluídos, com artigos que refletiam a realidade sócio política do Brasil e da América Latina. Os editoriais deste período assinados pelo sacerdote e jornalista Claudio Gregianin são indicativos de uma postura profética e teologicamente de vanguarda que reflete, no seu pequeno âmbito, os esforços dos veículos de

É muito útil observar o universo constituído pelo trabalho editorial empreendido por uma Congregação religiosa e seu vasto campo de atuação. Dados históricos apontados por Gonçalves (2008, p.70) são úteis para a nossa reflexão: "Quanto a esta última particularidade, inspirados na profícua obra do fundador da ordem, Antonio Claret, os claretianos desenvolveram uma rede de comunicação que correspondia a um expressivo domínio. Até 1911, além da Revista Ave Maria, que era o carro-chefe da imprensa claretiana, funcionavam o Amigo do Lar em Salvador, Lourdes em Belo Horizonte, Rosa Mística em Campinas, A Paz no Rio de Janeiro, A Esperança em Ribeirão Preto e A Parochia de Santos. Os claretianos também mantinham publicações em outros países americanos como o México (La Esperanza), Peru (La Accion Católica), Chile (El Faro del Hogar, El Inmaculado Corazón de Maria), Colômbia (La Virgen de la Popa, El Voto Nacional, La Aurora) e Argentina (El Inmaculado Corazón de María). Fora das Américas, os claretianos também administravam um vasto complexo editorial. Em Madri, editavam El Íris de Paz, Illustración del Clero, El Legionario de la buena prensa, Los Apostoles de Guinea. Em outras regiões da Espanha circulavam El defensor de la infancia e Los Ecos del Jerez. Como colaboradores participavam da edição de Los Ecos de Aranda, Ecos de Calahorra e Ecos del Ferrol. Na Itália, dirigiam a revista científica Commentarium pro religiosis, e folhas de propaganda como Raggi de Esperanza e La Marcel. Na Inglaterra dirigiam a revista The Star of the Sea, e na África, La Guinea Española” 
comunicação católicos não só do Brasil, mas de todo o continente latinoamericano, na construção de uma espiritualidade encarnada no contexto e de uma espiritualidade menos devocional e mais martirial. Basta pensar no elenco de teólogos convidados para escrever em suas páginas, tais como: Leonardo Boff, Clodovis Boff, Maria Clara Bingemer, Frei Betto, Pedro Casaldáliga, João Batista Libâneo, José Fernandes de Oliveira, Cerezo Barredo, dentre outros.

A teologia que emerge das poesias de Pedro Casaldáliga nas páginas da Revista Ave Maria tem contornos de libertação. O sentido humano e o respeito pela vida que transparece na sua poética revela a opção fundamental realizada pela teologia da Libertação. O papel exercido por esta Revista de cunho popular foi a difusão, por todo o território nacional, de uma poética sensível e teologicamente portadora de uma experiência eclesial viva e profética. Casaldáliga, filho de camponeses da cidade catalã de Balsareny, nascido em 16 de fevereiro de 1928, foi o primeiro bispo de São Félix do Araguaia, defensor dos indígenas e que realizou sua Páscoa neste ano de 2020, sendo sepultado às margens do rio Araguaia. Como membro da Congregação dos Missionários Claretianos foi enviado ao Brasil no ano de 1968 para fundar junto com outros companheiros claretianos uma missão no Estado do Mato Grosso, exatamente em São Felix do Araguaia, onde posteriormente se tornaria bispo, por nomeação do Papa Paulo VI. Naquela circunstância viveu os anos rudes presenciando mortes absurdas, sofrendo pelas injustiças cometidas aos mais pobres, sendo alvo da violência políticopolicial e das incompreensões eclesiásticas. Neste contexto, Casaldáliga confessava que com tanta morte rondando qual onça para o bote, ele teve de aprender a viver apaixonadamente apegado à virtude da esperança: "Só se espera, diríamos, na medida em que se desespera. A esperança, penso agora, também é pobreza. Ninguém vai esperar se já está farto com seu eu, com seu agora, com seu mundo presente. Só espera quem vive o futuro" (CASALDÁLIGA, 1985, p. 16).

A paixão pelos esquecidos e pobres da terra foi o seu lema. Costumava dizer que, por sua veia poética e espírito compassivo, era incapaz de presenciar um sofrimento sem reagir. Aos que o interrogavam sobre sua identidade, preferia dizer poeticamente: "tomai-me por latino-americano, tomai-me simplesmente por cristão, se acreditais em mim e não sabeis quem sou!” (1988, p. 31). Já segundo entrevista concedida a Escribano (2007, p. 377), o bispo profeta do Araguaia dizia de si mesmo: 
Minha vocação natural é ser poeta. Eu considero que somos todos poetas, porém o poeta tem a sorte de podê-lo dizer. O poeta expressa o que todos sentimos. Esta é minha vocação. Não fui um bom poeta - digo-o com toda a sinceridade e sem pecar por vaidade - porque não me dediquei a isso. E muito embora o poeta já nasça como tal, é preciso que haja dedicação. Eu respiro poesia, tusso poesia, porém não me dedico a fazê-las. Isso não significa que quando escrevo alguma não a corrija mais ou menos, porém não me dedico a isso. Quando estava no seminário, houve um momento em que me propus a dúvida espiritual sobre se teria que renunciar à poesia. Por sorte a recuperei e me ajudou muito nesse Mato Grosso para gritar, para cantar, para rir, para chorar, para maldizer e para rezar. A verdade é que não me arrependo de haver renunciado a me dedicar totalmente à poesia. É uma de minhas renúncias por minha vocação missionária.

O perfil poliédrico de Pedro Casaldáliga foi delineado por Tamayo (2011) no livro La teologia de la liberación por meio de seis imagens, com dimensões que marcaram a vida e a obra desta figura emblemática para a história do Brasil, a saber: missionário, profeta, poeta, místico, teólogo e bispo. No entanto, por ocasião do falecimento de Casaldáliga, ocorrido em 8 de agosto deste ano de 2020, Tamayo (2020) amplia o horizonte e faz uma homenagem descrevendo ainda outras características do rosto do profeta do Araguaia. As imagens acrescentadas às anteriores apontam para as causas que marcaram suas lutas, como: revolucionário internacionalista; intelectual crítico; ecologista; defensor das causas indígenas e negra; defensor das causas das mulheres; promotor do diálogo intercultural, inter-religioso e inter-ético; operador da utopia em construção; construtor de uma espiritualidade contra hegemônica.

Casaldáliga sempre demonstrou grande sensibilidade artística e, nas horas duras da perseguição pela ditadura militar ${ }^{8}$, recebeu o calor solidário de Mino Cerezo Barredo tornando-se o desenhista e muralista de sua Prelazia9 mas, além disso, conforme testemunha o pintor era Pedro quem criativamente dava os nomes adequados a cada uma destas criaturas sacramentais (CEREZO BARREDO, 2008, p. 345) que em cores vivas e expressivas retratam a

8 Sobre a arte de Cerezo nesse contexto ver a recente publicação intitulada $A$ arte mural de Mino Cerezo Barredo no período militar brasileiro (FERNANDES, 2020).

9 A intercolaboração entre Pedro Casaldáliga e Cerezo Barredo foi desde a ilustração de diversas etapas da Revista Alvorada - boletim pastoral da prelatura - e desenhos para os subsídios pastorais da igreja de São Félix e, principalmente, os diversos murais da Prelazia que foram declarados, em 2005, como parte do Patrimônio Histórico e Artístico do Estado do Mato Grosso. Esta ação foi fundamental em termos da preservação, manutenção e proteção destas obras para a história cultural, política e religiosa do país. 
caminhada de seguimento de Jesus e suas implicações. De fato, os onze murais pintados para a Prelazia foram todos elaborados, discutidos e desenhados no intenso diálogo e conversa com Pedro Casaldáliga e os agentes de pastoral, sendo "cada um deles comentado por Pedro-poeta, em didáticos e luminosos poemas” (CEREZO BARREDO, 2015, p. 344).

Às poesias e imagens desses missionários claretianos reunimos a teologia de Vítor Westhelle. Esta conversa se dá tanto pela dimensão teológica de suas produções, como veremos no próximo tópico, quanto pelo caráter biográfico de engajamento nas lutas sociais do sofrido povo latino-americano. Westhelle, nascido na cidade de Taquara, no Rio Grande do Sul, no ano de 1952, pode ser considerado um dos mais brilhantes teólogos luteranos brasileiros. Fez seus estudos teológicos na faculdade da igreja luterana, atual Faculdades EST, seguindo para seu doutoramento na Lutheran School of Theology at Chicago, onde também atuou por vários anos como professor. Após o doutorado assumiu pastorado na cidade de Matelândia, no Paraná, envolvendo-se com os trabalhos da Comissão Pastoral da Terra, chegando a coordenar o núcleo regional. Entre 2011 e 2016, sem deixar seu vínculo com a faculdade de Chicago, assumiu a Cátedra de Pesquisa em Lutero na Faculdades EST. Instituição pela qual recebeu o título de doutor honoris causa em 2018, mesmo ano de seu falecimento. Um de seus filhos o representou na cerimônia de outorga do título ${ }^{10}$.

A luta por justiça e pela terra une missionários e pastor. Sobre sua atuação pastoral, Westhelle escreve o seguinte:

Enquanto trabalhava com agricultores sem terra no Brasil na década de 1980, procurei em vão categorias teológicas que eu pudesse usar para refletir sobre os próprios sujeitos existenciais e pastorais com que me deparava: milhões de pequenos agricultores expulsos de sua terra, famílias de agricultores sem terra que viviam anos infindáveis em barracas de plástico em margens de rodovias - espremidos entre o trânsito e as cercas das propriedades rurais subutilizadas ao lado. Desde aquela época, "espaço", "lugar" e outros motivos espaciais têm sido preocupações minhas e teologúmenos indispensáveis (WESTHELLE, 2008, p. 151, nota de rodapé n.1).

Nesse continente martirizado, teopoética e teologia da libertação são reflexos, não por último, de biografias engajadas com a dor e o sofrimento

10 Ver informações em: http://www.est.edu.br/noticias/visualiza/falecimento-prof--dr-vitor-westhelle. Acesso 03 nov. 2020. 
real de pessoas concretas em realidades bem localizadas. A poesia de Casaldáliga, a imagética de Cerezo e a teologia de Westhelle transpiram a concreticidade da realidade latino-americana. Como já indicado, há elementos espaciais e martiriais nas teologias presentes na poética e na imagética dos missionários claretianos, quer-se demonstrar, a seguir, que a teologia da cruz de Vítor Westhelle se configura não apenas em ponto de diálogo com aquelas produções artísticas, como pode fornecer ferramentas para uma hermenêutica escatológica delas.

\section{Expressões teológicas da cruz e da ressurreição}

Vítor Westhelle desenvolve uma teologia da cruz que é também uma teologia da ressurreição. Para ele, existe aí um movimento de revelação e escondimento em que a cruz revela a ressurreição e a ressurreição revela a cruz. No exposto se revela seu oposto (revelatio abscondita sub contraria specie). Os temas de fundo aqui são sofrimento e esperança. Com efeito, se quer demonstrar que: na poesia América Latina, de Casaldáliga, ao narrar a cruz, o autor também desvela uma esperança de resistência; e que no mural do Santuário dos Mártires da Caminhada de Cerezo, bem como na poesia que Casaldáliga dedica a ele, a ressurreição não apaga as feridas.

O teólogo luterano propõe uma leitura da cruz e da ressurreição por seus lados manifestos e abscônditos. A cruz manifesta expressa dor, sofrimento e violência. A cruz oculta é representada pelo sepulcro, pelo sofrimento escondido (o sábado de silêncio). Ela, para além do derrotismo, conclama para um trabalho de amor e de luto (deixar ir). A ressurreição manifesta fala da possibilidade da esperança mesmo em meio ao sofrimento. Insurreições e empoderamento possíveis ainda que frente a uma experiência de total negatividade. Sobre o texto de João 20 em que se narra a visita do ressuscitado aos seus discípulos enclausurados, Westhelle comenta: "A paz não é uma festa alegre com o ressurreto, escondidos, em um recinto fechado, de um mundo que fabrica cruzes" (WESTHELLE, 2008, p. 178). A ressurreição oculta comunica que as cicatrizes permanecem e que se pode assumir a própria vulnerabilidade. Ela reconduz para a cruz manifesta, para o reconhecimento do corpo torturado e de um esvaziamento em solidariedade. (WESTHELLE, 2008, p. 175-179). 
Ana Beatriz Dias Pinto

\section{A ressurreição e a cruz}

Comecemos pela ressurreição. O mural de Cerezo é reluzente, seu tema é a ressurreição dos mártires numa caminhada vitoriosa contra os sofrimentos do mundo.

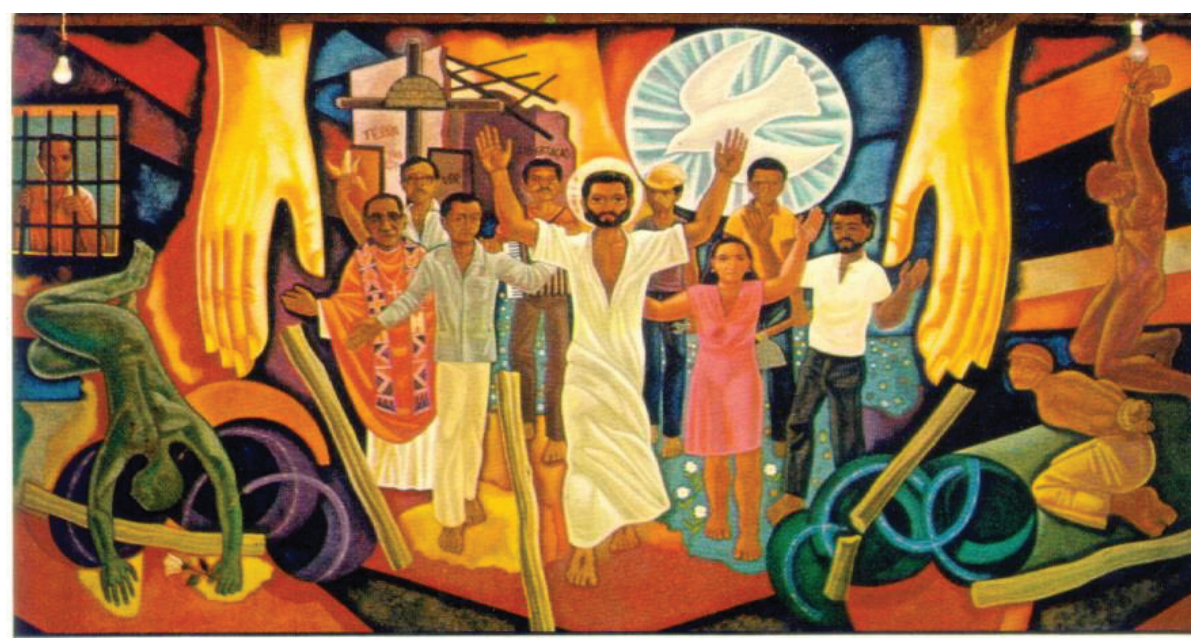

Imagem 1: CEREZO BARREDO, Maximino. O maior amor, obra mural, Santuário dos Mártires da Caminhada, Ribeirão Bonito-MT, Prelazia de São Felix do Araguaia,1986.

A forma artística presente no Santuário assume características de uma paixão por sentir e viver o Reino, pelo qual o Verbo de Deus se fez carne. É o próprio Casaldáliga quem explica o significado do Santuário como lugar da oposição a qualquer violência:

é o primeiro santuário dedicado aos nossos mártires e quer ser uma homenagem a todos os nossos irmãos que se mostraram capazes de permanecer no amor até o fim, lutando pela causa indígena, pela causa do lavrador, pela causa do operário, contra a tortura. Vinte e um desses mártires estão aí com suas fotos e uma inscrição que lhe dá o título específico, ligado à causa de sua morte. Por exemplo: mártir da verdade, mártir da Pastoral da Juventude... Eles representam todos os nossos irmãos martirizados, os martires anônimos, as crianças de Ronda Alta, os mártires anônimos do Nordeste (CASALDÁligA, 1988, p.233).

A imagem do mural torna-se ainda mais expressiva se acompanhada das palavras poéticas de Casaldáliga que revelam a densidade teológica expressa 
pela estética de Cerezo. Aqui não entra em jogo tanto a genialidade artística e criativa de ambos, mas como defende o teólogo fundamental Sequeri (1993, p. 31) trata-se de uma obra que "fala a língua da dedicação à justiça de um mundo possível escavando - também dramaticamente quando necessário - nas chagas do mundo real". Tal como explicitou Boff (2005, p. 8), no prefácio ao livro sobre os Murais da Libertação, pode-se notar que "as duas artes, a pictórica e a poética, se completam e se iluminam mutuamente".

Casaldáliga, no poema que criou para o mural dos mártires, não se limitou a elaborar, em versos líricos, as emoções e sentimentos do povo, mas ofereceu uma interpretação no horizonte escatológico ensinando a ler o martírio como confissão-testemunho da fé no Reino de Deus. A característica principal desta poesia lírica permite sentir a densidade de vivência e de comunhão pessoal dele com estes acontecimentos e martírios. Na verdade, tanto o mural quanto a poesia tratam temas vitais como o seguimento de Jesus e a luta contra os instrumentos de opressão. A poesia de Casaldáliga é expressão daquela necessidade que a fé tem de se justificar, tal como expresso em 1 Pedro 3,15. E não só: o estilo de escrita de Casaldáliga é intenso e expressivo porque está carregado de interrogações sobre as contradições na América Latina e, assim, na sua expressão literária e poética emerge imediatamente as causas de uma vida que declarou maldita toda a cruz exibida pelos opressores. As poesias para Casaldáliga são um instrumento para a denúncia da opressão por meio da ironia, da sátira ao prepotente. As poesias são a forma de fazer descer do trono da arrogância os poderosos como cantou Maria no seu Magnificat. Casaldáliga (1988, p. 17) afirma: "é preciso amá-los depojando-os" .

A primeira parte do poema que Casaldáligia dedica ao mural de Cerezo põe em evidência temas próprios da pintura de Cerezo e aqui destacamos apenas dois. Em primeiro lugar as grandes mãos divinas que aparecem como um escudo de proteção frente ao clima de violência que atravessa o mural expressando o contexto latino-americano. Conforme enfatiza Favre (2012, p. 166) “a composição no seu conjunto é dinâmica mas clara: mostra com evidência narrativa os fatos e os protagonistas da recente história, de tal modo que sejam reconhecidos também pelos mais humildes fiéis". Em segundo lugar, destaca-se a figura de Jesus que aparece com as chagas, que para Casaldáliga é a página predileta do Evangelho, pois mostra a Páscoa no seu dinamismo de morte e ressurreição. 
Ana Beatriz Dias Pinto

As mãos do Pai amparam o caminho.

E o Espírito sela a Caminhada, com as asas abertas, Paz adentro

Jesus, com as feridas

de Testemunha fiel, rompe a marcha,

Primeiro dos nascidos

da morte vitoriosa.

E sua mão cancela

a vigência das trevas

$\mathrm{Na}$ sequência o poeta descreve outro traço típico do estilo de Cerezo que traduz a figura de Jesus de Nazaré como aquele mestiço que sintetiza todas as dores e martírios sofridos na América latina. O rosto de Jesus carrega todos os nomes e um destes grandes nomes é o de Oscar Romero e outros que nos fazem recordar a Ceia. A Eucaristia é o Banquete Pascal ao qual os fiéis reunidos em torno da mesa são convidados a participar comungando do Corpo e do Sangue do Senhor. Tal comunhão sacramental deve produzir frutos de libertação expressas na teimosa rebeldia, na comunhão recíproca, no trabalho organizado e na marcha pela justiça.

No rosto d'Ele,

o rosto cotidiano do Povo.

Junto d'Ele, colegas de combate,

João Bosco ${ }^{11}$, Margarida,

Rodolfo, Gringo, Tião,

Josimo, Chico, Santo,

...Tantos! Tantas!

São Romero celebra Eucaristia

no altar do Continente,

com a estola dos Maias redivivos.

Marçal empunha o milho,

pão nosso da Ameríndia.

As ferramentas gritam

a força do trabalho organizado,

o fraterno poder das mãos unidas.

11 João Bosco, assassinado por um policial quando estava na companhia de Casaldáliga, é lembrado na inscrição da cruz representada por Cerezo. Seu nome é lembrado também na liturgia da Missa da Terra Sem Males: "A Missa invoca seus Santos: do lendário Montezuma até o missionário João Bosco, fuzilado, a meus pés, pela Política Militar, na delegacia de Ribeirão Bonito" (CASALDÁLIGA, 1980, p. 17). 
Bem por trás da cadeia, derrubada

a golpes de teimosa rebeldia, vinga a aurora do Reino.

$\mathrm{E}$ as cercas da cobiça se retorcem, cortadas pela marcha justiceira.

$\mathrm{Na}$ terceira parte temos a recordação dos que foram torturados, silenciados e feitos desaparecer pelos regimes autoritários. No entanto, há sim a memória das testemunhas que tombaram entre as flores e sempre em comunidade.
Ainda há torturados
nas masmorras da noite.
Há desaparecidos, nos cumplices silêncios.
Inutilmente, império, inutilmente!
Nossos caídos tombam
com a flor da esperança
nas mãos ressuscitadas.
Nossos mortos caminham, arrastando consigo a História Nova.
Contra os berros da morte, as palavras da vida:
Terra! Libertação!
- canto coral da nossa Caminhada.

Nuvem de testemunhas nos sustenta a coragem. Nós somos testemunhas de testemunhas, somos herdeiros do seu Sangue. Com eles caminhamos, libertando o futuro.

Por Ele caminhamos, Horizonte e Caminho. Filhos da mesma Graça, Nascidos de igual Monte, Memória d'Ele e deles, Celebramos a Páscoa. 
A obra de Cerezo e os versos de Casaldáliga transpiram ressurreição e expressam um ambiente de celebração. Contudo, não deixam de representar o outro lado da ressurreição, os ressuscitados são os mártires assassinados na luta por justiça social, o nazareno ressurreto carrega suas chagas e vai à frente na caminhada. A beleza e esperança da ressurreição são traduzidas em prática de resistência aos poderes da morte. A arte mural opera entre denúncia e anúcio, o sofrimento ainda está ali às margens, mas também no corpo dos ressuscitados, vê-se nos pés e nas maõs de Jesus as marcas do martírio. A ressurreição manifesta expressa ânimo, empoderamento, mas, como adverte Westhelle, não se pode deixar transformar num ressurreicionismo, isto é, num devocionalismo desencarnado que, em última análise, acaba desrespeitando a própria memória dos mártires. A ressurreição movimenta o corpo de Cristo para fora do sepulcro, para ser sinal de vida entre os viventes. Aquilo que Westhelle identifica como ressurreição oculta é a percepção de que, mesmo diante do anúncio da vitória da vida contra a morte as cicatrizes permanecem, faz reconhecer a presença do sofrimento e reconduz para a cruz. Assim, a esperança da ressurreição está acompanhada pela realidade da cruz assumida no martírio, e ela tem lugar concreto - América Latina.

\section{A cruz e a ressurreição}

Não sem intenção a edição de agosto de 1992 da Revista Ave Maria reuniu um recorte do mural de Cerezo e uma outra poesia de Casaldáliga em que o tema preponderante é a cruz.

A poesia intitulada América Latina, de Casaldáliga, apresenta o itinerário da crucificação à ressurreição e de volta. O corpo de Jesus é também o corpo da própria terra latino-americana (Ameríndia, Pátria Grande) e de seus habitantes. É caminho de martírio que se distribui por uma vida inteira ${ }^{12}$. O lugar de onde e para onde a poesia fala é a cruz. O Domingo de ressurreição e libertação está no horizonte, mas o que se vive na pele é a Sexta-feira. Dizer a cruz se torna o grande desafio da teologia cristã. Ela é espaço e tempo que desafia à linguagem e o pensamento. Mesmo assim, após o silêncio

12 Em poema dedicado à Casaldáliga Pedro Tierra (1974) escreve o seguinte: "Buscam o martírio? O martírio não se busca, / se vive. Como se vive / 'la muerte que da sentido a mi vida...' / Percorrerão o pó dos caminhos, / a vasta geografia do drama urdido / pelos filhos de êxodo e da miragem." 


\section{AMÉRICA LATINA}

Sobre sua longa morte e esperança desnudo o corpo inteiro

- a palavra, o sangue, a memória definitivamente

será minha cruz

a América Latina.

Deus, pobre e massacrado,

grita ao Deus da Vida

desta coletiva cruz

alçada

contra o sol do Império e suas trevas, diante do véu do tempo estremecido.

Amanhã será Páscoa

— porque Ele já é amanhã para sempre. (Revestida de chagas e supresas, virá pelo jardim a Liberdade, irmãos.

E há que se pôr ternura nas quenas despertas

e quebrar os aromas solidários

- e desafiar o medo do sepulcro desarmando os guardas.

Mas hoje ainda é Sexta-teira Santa.

Todos somos testemunhas,

entre dados e lancas.

enquanto a mãe chora sobre o fillho caido.

Eu não quero negar-me a esse mistério. Eu não quero negar-te.

América Latina

será minha cruz definitivamente.

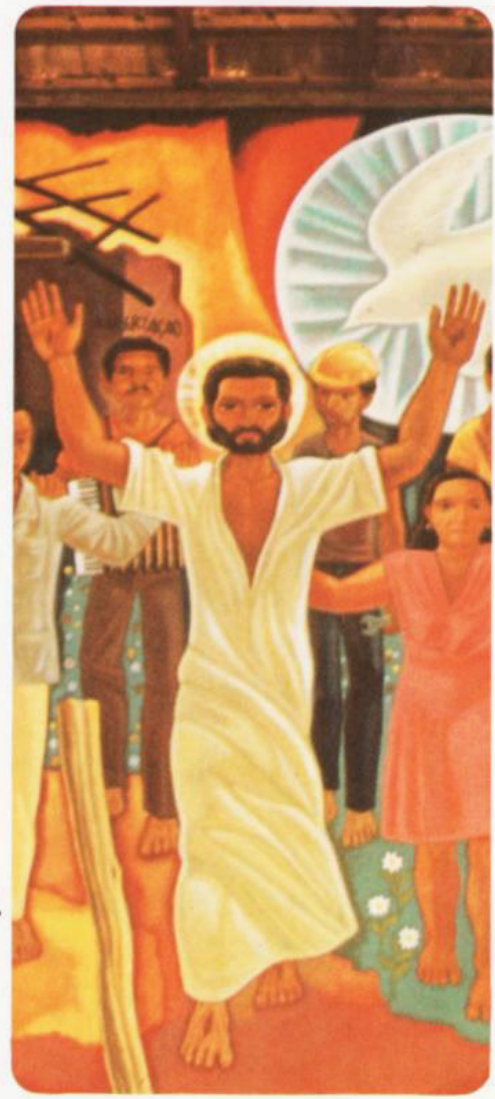

D. Pedro Casaldáliga

Imagem 2: Poesia "América Latina" de Pedro Casaldáliga. Mural "O maior amor" de Cerezo Barredo. Contra-capa da Revista Ave-Maria, agosto de $1992^{13}$.

13 Nesta edição encontra-se a intencional conexão entre a poesia América Latina, de Casaldáliga, e o recorte de uma imagem do grande mural produzido por Cerezo, em 1986, em Ribeirão Bonito. Nota-se também a transição, paulatina, de páginas em preto e branco para o uso mais frequente da impressão colorida que a Revista começava a implantar. 
Ana Beatriz Dias Pinto

do sábado, arrisca-se dizer algo. Aquilo que é dito, no entanto, justamente diante do excesso de sentido daquilo que quer ser representado não pode ser completamente descoberto. Com efeito, o que está em jogo na cruz é uma dinâmica de revelação e ocultamento ${ }^{14}$. A cruz reorienta o olhar para as experiências humanas nos limites do abismo, dos limiares, das fronteiras, do absurdo. E ajuda a linguagem a dizê-los:

Sobre sua longa morte e esperança

desnudo o corpo inteiro

- a palavra, o sangue, a memória -

definitivamente

será minha cruz

a América Latina.

O topos encarnado revela a vida escondida na morte. A vitória dos poderosos sobre o corpo estendido é sua derrota. O sangue derramado é semente. A cruz não é o fim, mas tempo crucial e margem de virada onde, simultaneamente, o fim é o começo. Lugar de encontro com um tremendum que é, ao mesmo tempo, fascinans (WESTHELLE, 2008, p. 164) ${ }^{15}$.

Segundo Marzec (2008, p. 297) na poesia de Casaldáliga encontra-se um ritmo que possibilita a combinação de "lirismo e espiritualidade, ternura e força, compromisso e fé", é uma poesia de compromisso ético-social situada desde o lugar dos pobres e onde a vida deles encontra ressonância com ecos de indignação e apelos de libertação. Na poesia de Casaldáliga aqui analisada, o fim é também seu começo. A América Latina, cruz anunciada na primeira estrofe, é o culmine da construção literária. Entre o começo e o fim, entre a cruz de Jesus e as de hoje está a partilha do martírio e da esperança contra toda esperança. Nas palavras de Westhelle (2008, p. 164-165):

\footnotetext{
14 A terminologia apokalypsis e revelatio indica tanto um des-velamento, quanto um velamento redobrado (absconditus et revelatus). (WESTHELLE, 2008, p. 161).

15 A mesma perspectiva teológica encontramos no livro Cristologia desde a América Latina, de Jon Sobrino, uma das leituras preferidas de Casaldáliga porque neste livro o jesuíta basco insiste no aspecto do seguimento de Jesus na atualidade e evoca a necessidade de comungar da vida e destino de Jesus como sinal de esperança. Ele diz: "De um ponto de vista qualitativo, a ressurreição de Jesus se converte em símbolo universal de esperança na medida em que todos os homens participam de alguma forma da crucificação; em outras palavras, na medida em que a morte de todo homem tenha a qualidade da crucificação" (SOBRINO, 1985, p. 221).
} 
[...] é de onde está o perigo que vem a libertação, mas será que queremos ser salvos e salvas? Ou ansiamos, antes, por estar seguros? Não é essa a mensagem, a lição que aprendemos daquele outro apocalipse, o apocalipse de Jesus Cristo? Entre aquele e o nosso há uma trilha que é marcada pelo sangue das pessoas que foram testemunhas, foram mártires [...], não só porque confessaram Jesus, mas porque elas próprias se encontram junto à linha limítrofe daquilo que lhes era familiar, porque tinham aprendido a manter o olhar firme e a interpretar seu próprio apocalipse à luz e à escuridão daquele outro que testemunharam. Os mártires são necessários, pois somente eles, desde Estevão até Dom Oscar Romero, podem nos mostrar o caminho de volta para aquele apocalipse que nos reorienta e nos permite ler os sinais dos tempos e lugares, enfrentando o estranho cheios de esperança - mas que é uma esperança contra toda a esperança.

O martírio, a cruz carregada por cristãos e cristãs, ilumina e atualiza o apocalipse de Jesus. $\mathrm{O}$ apocalipse de Jesus, ilumina e atualiza a caminhada dos mártires. "Dietrich Bonhoeffer chamou isso de custo do discipulado. Mas, se esse é seu custo, quem pode ser salvo? Quantos, digamos, professores com estabilidade deixaram, estão deixando ou estão dispostos a deixar a segurança para trás a fim de ser salvos?” (WESTHELLE, 2008, p. 165).

Mas hoje ainda é Sexta-feira Santa.

Todos somos testemunhas [mártires],

Entre dados e lanças,

Enquanto a mãe chora sobre o filho caído (grifo nosso).

Segundo os relatos evangélicos, do testemunho das mulheres, desde a mãe que chora a morte do filho, até aquelas que graciosamente observam o sábado e desejam prestar-lhe um último serviço, nasce a esperança e a prática da ressurreição. Esta escatologia não é utópica, mas heterotópica ${ }^{16}$, cresce em outros lugares, mais especificamente no liminar, nas margens ${ }^{17}$. "Se concebermos a visão escatológica como um outro mundo que acontece, esse outro mundo poderia ser o próprio mundo do outro, do outro que é diferente e excluído de nosso mundo" (WESTHELLE, 2008, p. 118). Uma

\footnotetext{
16 A expressão remete aos estudos de Michel Foucault (2013) que, ao tratar da questão de espaços outros, distingue utopia de heterotopia. O primeiro é um lugar sem alocação real, o segundo, por assim dizer, seria uma utopia realizada, espaços outros que operam em lógicas distintas daquelas dos espaços culturais comuns.

17 Roberto Zwetsch (2013), em obra organizada em homenagem a Vítor Westhelle, ao analisar um dos poemas de Casaldáliga, fala das fronteiras institucionais.
} 
teologia da cruz, portanto, é também uma teologia dos crucificados. "É uma maneira de reconhecer o outro lado, o lado oculto da história, as margens, os excluídos, os abandonados, o ‘povo crucificado' (Ignacio Ellacuría), as ‘não-pessoas’ (Gustavo Gutiérrez) como o espaço privilegiado da autorevelação de Deus” (WESTHELLE, 2008, p. 119). O encontro com o Cristo crucificado é concebido como uma mudança de perspectiva (metanoia) que se desdobra em solidariedade com o sofrimento das pessoas e do mundo. Uma teologia cristã que nega a cruz é incapaz de enxergar vida em meio ao sofrimento e nega a ambiguidade da existência (cf. WESTHELLE, 2008, p. 121). O texto dos discípulos de Emaús fala sobre uma teologia da cruz que começa quando o discurso acaba, é no partir do pão que a conversão e o engajamento com uma nova prática acontecem e eles voltam para o lugar da crucificação. As mulheres, por sua vez, são as primeiras testemunhas. "Para aquelas mulheres, aquela cruz não era ainda o fim de tudo; ainda havia um trabalho por fazer" (WESTHELLE, 2008, p. 127). As mulheres não o abandonaram, além de ficarem aos pés da cruz, também se organizam para cuidar do corpo ferido e já sem vida.

Depois da preparação e depois de terem observado o sábado, elas retornaram ao sepulcro para ungir um corpo morto putrescente apenas para ser surpreendidas e aterrorizadas ao encontrar o túmulo vazio e aquele mesmo corpo vivo. [...] A surpresa está aí quando realizam um trabalho de luto e amor. Em meio à sua dor, em face do cadáver do Amado, essas mulheres praticaram o ato improvável de amor sem esperar que ele alguma vez fosse retribuído. Uma teologia da cruz é sempre o outro lado de uma prática da ressurreição, e uma prática da ressureição é o outro lado de uma teologia da cruz (WESTHELLE, 2008, p. 128).

O sábado entre a crucificação e a ressurreição é ausente de palavra, mas é invadido pela fragrância dos perfumes que, numa economia da graça, são comprados para um corpo sem vida. O Espírito, para o autor, é o vento que espalha aquele aroma e sussurro possível diante da ausência da palavra. Esse ato de serviço gratuito sem chances de retribuição é denominado por Westhelle, com base em Wendell Berry, de prática da ressurreição ${ }^{18}$. Um

18 Roberto Zwetsch, teólogo luterano e missionário, atuou por muitos anos no contexto amazônico em Rondônia e no Acre, respectivamente com os povos Surui-Pater e KulinaMadiha. Na apresentação de uma obra organizada em homenagem a seu amigo Vítor e lançada durante evento de outorga do título de Doutor honoris causa a Westhelle pela Faculdades EST, escreve o seguinte: "Ocorre-me registrar mais um espanto: sua fala 
movimento de esperança contra toda a esperança (WESTHELLE, 2008, p. 182-183). "Essa é a tarefa dos seguidores e das seguidoras de Cristo: não permitir que a história termine em calamidade, não permitir que o passado seja fechado, contra toda evidência, contra toda esperança" (WESTHELLE, 2008, p. 129).
E há que se pôr ternura nas quenas despertas
e quebrar os aromas solidários
e desafiar o medo do sepulcro
desarmando os guardas.

O Domingo de Páscoa nasce, mas antes dele, está o sábado e o silêncio. Westhelle aborda o Shabbat em conexão com a noção aristotélica de theoria, que está acompanhada das outras duas artes humanas, a saber, a poiesis e a praxis ${ }^{19}$. A teoria é aproximada da contemplatio, do Shabbat. É vazio que carece ser lamentado e suportado, ócio. Diferente da parousia (presença) é apousia (ausência). (WESTHELLE, 2008, p. 143-145). O vazio do sábado, reflete o sentido da creatio ex nibilo como criação a partir do nada - dor, mal, sofrimento (WESTHELLE, 2008, p. 113). Diante do fracasso da morte, a cruz revela o que está oculto, o que é oposto ao exposto. Guardado o silêncio

sobre as mulheres na passagem do sábado após a sexta-feira terrível da cruz, da agonia e da derrota e que - por amor ao Amado - saem na madrugada do domingo para ir ao encontro do lugar onde o puseram e assim realizar um último gesto de amor e cuidado. Este gesto gratuito e sem sentido se torna gesto-testemunbo de algo que mudou a sua história e a nossa história, e se tornou gesto de ressurreição, de um anúncio transformador, cuja memória havemos de honrar se somos do povo de Jesus. Ele ressuscitou ou foi ressuscitado, se melhor o entendemos. E então Vítor saca desse espanto uma frase que não cessa de nos causar desconforto porque com cinco palavras ele une o que parece ser impossível de compreender: 'É hora de praticar ressurreição"' (ZWETSCH, 2018, p. 9).

19 "O teatro grego serve como uma boa analogia para a distinção das artes humanas de Aristóteles. A pessoa que escreve uma peça de teatro ou constrói um palco está engajada em poiesis; suas atividades resultam em produção, um resultado do trabalho deixado objetivamente inscrito na peça ou erigido no palco e cenário. Praxis é o que os atores fazem no palco; sua atuação não resulta em um produto objetivo; o fim, o telos, da praxis é representar por representar bem. Theoria é a atitude imperturbada da plateia de captar atentamente o que está acontecendo no palco. Embora todas as três possam, às vezes, acontecer simultaneamente ou se sobrepor, é possível estabelecer suas características distintas" (WESTHELLE, 2008, p. 135). 
e o ócio, torna-se novamente possível a ação e o encontro com a vida, eis o mistério da ressurreição ${ }^{20}$. (cf. WESTHELLE, 2008, p. 147, 163).

\author{
Deus, pobre e massacrado, \\ grita ao Deus da Vida \\ desta coletiva cruz \\ alçada \\ contra o sol do Império e suas trevas, \\ diante do véu do tempo estremecido.
}

A inversão se dá neste (des)velamento de sentido, de que na própria cruz, levantada pelas autoridades políticas e religiosas já está o símbolo da ressurreição. Casaldáliga capta isso com toda destreza ao dizer que a cruz, agora não mais apenas de Jesus, mas coletiva, é alçada não como sinal da derrota do nazareno, mas como estandarte de resistência. A ressurreição representa uma prática ativa e consciente em meio ao sofrimento ${ }^{21}$ (cf. WESTHELLE, 2008, p. 171).

A cruz manifesta reflete Jesus, o povo e o continente crucificados, é um chamado à ação, de estar ao lado dos crucificados e de narrar suas histórias para que as cruzes, sejam elas quais forem, que foram erguidas pelos algozes possam ser invertidas contra eles. Como diria Ricoeur (2002), existe uma dívida moral com as vítimas, suas histórias precisam ser narradas, malfeitores devem ser nomeados, as pessoas violentadas não podem ser culpabilizadas. Este trabalho de memória tem a ver com um trabalho de luto, um deixar ir, que percebe que há o irreparável. Este movimento nos direciona à compreensão da cruz oculta como o sábado, o silêncio, o vazio a

20 De modo semelhante, o já citado Jürgen Moltmann, também elabora a conexão entre a sexta-feira e o domingo de páscoa em perspectiva ética: "Conquanto a expectativa da parusia está determinada mais pela recordação de Cristo, ela conclama a uma nova forma de vida na comunhão com Cristo. O 'dia' está próximo, por isso já podem 'ressuscitar' nesta vida [...]. Eles são 'filhos da luz' (Ef 5,8s) e deverão viver como filhos da luz, abandonar 'as obras das trevas' e 'tomar as armas da luz' (Rm 13,12). Com esse simbolismo da luz é descrito o reino de Cristo e a nova criação. Embora ainda seja escuro neste tempo da violência e da injustiça, os crentes podem antecipar a luz da nova criação e viver já aqui do futuro de Cristo" (MOLTMANN, 2009, p. 498).

21 A relação entre ética e sofrimento já tem sido desenvolvida no diálogo entre teologia e literatura, cita-se como referência a recente publicação $O$ sofrimento dá o que pensar: teologia pública em diálogo com a literatura marginal (ZEFERINO, FERNANDES, 2020). 
ser suportado, do qual pode emergir uma prática de ressurreição - como a poesia de Casaldáliga ou a arte mural de Mino Cerezo.

\section{Considerações finais: uma escatologia espacial-martirial}

Ali onde está o sofrimento podem nascer a resistência e a esperança a ressurreição. Ali onde está a ressurreição encontram-se também as chagas, as cicatrizes, as feridas. Esta teologia da cruz e da ressurreição teorizada por Westhelle e artisticamente potencializada por Casaldáliga e Cerezo deixa transparecer uma escatologia espacial-martirial ${ }^{22}$. O compromisso de libertação assumido por esses claretianos e por esse luterano fazem reconhecer que a teologia nasce dos espaços concretos das vidas das pessoas, suas lutas, sofrimentos e alegrias.

Para Casaldáliga a própria igreja torna-se um lugar na medida em que passa a ser conhecida como sacramento de salvação, como povo de Deus em participação e solidariedade. Esta experiência eclesial deixa marcas na história particular de uma comunidade. Neste caminho o Vaticano II passou a ser descoberto por Pedro, nas margens do Araguaia, como "a boa nova da Igreja Particular" (CASALDALIGA, 1988, p. 142), fazendo com que a atenção aos sinais dos tempos fosse completada pela atenção aos sinais que provém dos lugares com os quais um homem ou mulher de igreja se comprometem. O Vaticano II afirma que a Igreja é "comunidade de fé, de esperança e de caridade (LG 8) ou "comunhão de vida, de caridade e de verdade" (LG 9). Esta é a realidade eclesial nuclear.

Para Westhelle (2008, p. 151), “[...] algumas das mais importantes experiências sociais que afetam as pessoas em todo o mundo são primordialmente experiências espaciais - migração, falta de teto, de terra, deslocamento, invasão, ocupação militar, confiscamento de terra, demolição do lar". Além de outros espaços como aqueles relacionados à classe social.

22 Cabe indicar que a dimensão espacial da escatologia é trabalhada por Westhelle também em outras obras, ele dedica à questão um capítulo em seu livro sobre eclesiologia (cf. WESTHELLE, 2017), mas é em Escathology and Space que ele se empenha de modo mais detido ao tema (cf. WESTHELLE, 2012). Por outro lado, é muito curioso pensar que tal perspectiva é também o horizonte que a clínica contemporânea assume quando no processo psicanalítico fala de dois momentos fundamentais do percurso existencial (SAFRA, 2006, p.158): o analisando deve realizar um caminho de busca do seu lugar originário (Arché) e apropriar-se do sentido último que lhe torna singular (Telos) no desenvolvimento de sua existência. Quando estes dois momentos acontecem significa que a pessoa experimenta o encontro de um lugar existencial singular e significativo. 
O teólogo luterano indica que a questão espacial na escatologia não recebeu muita atenção da teologia, sendo um ponto cego do pensamento ocidental que pode estar ligado à expansão colonial em que os territórios conquistados pela Europa cristã talvez tenham esvaziado o sentido de uma espera espacial, fazendo restar apenas a dimensão temporal da escatologia (WESTHELLE, 2008, p. 158). No entanto, a escatologia poética de Casaldáliga, assim como a pictórica de Cerezo e a teológica de Westhelle tem lugar (topos):

Pedro Casaldáliga, bispo, poeta e teólogo brasileiro, expressou isso nos seguintes termos, explicando que a tarefa da igreja como sacramento do mundo é atentar para os lugares: “os 'sinais dos tempos' deviam se completar com os 'sinais de lugares"'. Ou como diz um de seus aforismos: "A Palavra Universal fala dialeto” (WESTHELLE, 2008, p. 160).

Nota-se, portanto, um movimento contínuo entre cruz e ressurreição que funciona como uma metáfora do sentido da vida - entre sofrimento e esperança. A poesia de Casaldáliga e o mural de Cerezo expressam que o martírio tem lugar. É justamente ao encarnar a realidade concreta de determinados espaços que o testemunho se torna tão decisivo. Os mártires de El Salvador, mencionados na introdução deste trabalho, foram martirizados em virtude das lutas assumidas lá onde estavam; Dietrich Bonhoeffer poderia ter saído da Alemanha, mas escolheu permanecer em seu país; Pedro Casaldáliga $^{23}$ encarnou o Mato Grosso de tal modo que viveu um martírio

23 "Em mim, a morte tem sido sempre um pouco como naquela canção do Terço: "Soy el novio de la muerte". Não sei bem por quê. Parece-me que é um pouco de tudo. Pode inclusive ser um problema de temperamento; isso eu deixo para os psiquiatras. Parece-me que é um pouco de vivência de infância. (Vi, menino, aqueles mártires da zona vermelha, acompanhado por tantos sentimentos e por aquele terror, aquele medo...) Parece-me que seja um pouco - digo eu - raiz de mística hispânica. E - por que não? - me parece que seja um pouco de graça. Eu creio - 'creio' - com toda a gratidão e com toda a simplicidade que o Senhor me deu esta vocação. Se algum dia acontecer-me de esta vocação não se realizar, se eu morrer aos noventa e tantos anos e me for dado viver até ficar estendido numa cama ou em um sofá, de qualquer forma a presença do martírio em minha vida creio que terá sido como um sacramento fabuloso. Todas aquelas famosas meditações nossas sobre a morte, e os livros drásticos de Jó, os livros sapienciais ou as coplas de Jorge Manrique, e toda a nossa ascética e a literatura da morte que a gente tem experimentado, creio que tudo fica pequenininho ao lado de uma vivência concreta de martírio em que se descobre uma espécie de vocação, se perfila uma aspiração, se concretiza a petição da gente a ser autêntica, não é? A colocar-se inteiro. E, neste sentido, essas mortes que eu vim vivendo por um lado me fizeram sentir de um modo drástico a injustiça. E daí nasceu em mim essa paixão pela justiça e pela liberdade" (CASALDÁLIGA, 1988, p. 234) 
por décadas, traduzindo suas experiências em poesia, não em sua língua mãe, mas no idioma que acompanhou sua encarnação na realidade brasileira. Com Casaldáliga, Cerezo e Westhelle, pensa-se, portanto, numa escatologia espacial-martirial, em que o lugar dá forma ao testemunho.

Como indicado no tópico anterior, Westhelle propõe uma abordagem da relação cruz e ressurreição por meio da dinâmica revelação-abscondicidade, o que o leva a reler as estações da via crucis - inspirada no símbolo do infinito $(\infty)$ - em que a cruz manifesta leva à cruz oculta, esta se dirige à ressurreição manifesta que, por sua vez, está conectada com a ressurreição oculta, a qual, aponta novamente para a cruz manifesta. Neste caminho entrecruzam-se o testemunho (martyria) e a esperança da transformação. Não seria justamente esse o caminho proposto por Casaldáliga? Não se trata agora de se tentar decifrar sua poesia com o diagrama westhelliano, mas, em América Latina, há um movimento que se inicia na cruz, passa pelo martírio e esperança no horizonte da ressurreição e retorna para a cruz. A nova cruz, contudo, já é prática de ressurreição. “[...] O tempo não está vazio, pois há um itinerário, um movimento através de espaços com uma trajetória muito clara. O movimento vai do limite, do fim (Sexta-Feira Santa, a cruz, o sepulcro) para um centro (o lar, o Shabbat) e então de volta para a margem (Domingo, Páscoa, o sepulcro revisitado)" (WESTHELLE, 2008, p. 183). Há, na poesia de Casaldáliga, um jogo de revelação e abscondicidade pelos tempos e pelos espaços. A Sexta-feira é encarnada, estar ao lado dos crucificados é o martírio assumido, mas no subterrâneo da morte aparente está o Domingo que nos visita. $\mathrm{O}$ apocalipse de Jesus dá forma às interpretações das várias cruzes, bem como sustenta um soerguimento de resistência. A ressurreição é a vida que pulsa em meio ao sofrimento, é um levantar-se ou ser erguido contra toda injustiça. Os mártires ressuscitados estão em movimento na pintura de Cerezo, nos versos de Casaldáliga e na teologia de Westhelle. Ousa-se afirmar que, para eles, estar ao lado da cruz é, simultaneamente, um chamado a praticar ressurreição.

A clareza do pensamento e a expressividade da forma poética, em língua portuguesa, elaborada pelo apaixonado profeta do Araguaia Pedro Casaldáliga nos instigou a propor um caminho de reflexão que pode ser articulado aqui a partir do conceito de uma escatologia espacial-martirial que serve para mostrar os arranjos desenvolvidos neste artigo. As conclusões as quais chegamos, depois deste percurso, relacionam-se com a necessidade de se construir hoje espaços liminares, isto é, espaços intermediários de tensão onde os polos vida e morte; 
Ana Beatriz Dias Pinto

imanente e transcendente; morte e ressurreição; tremendum et fascinans possam entrar em diálogo. No Império Romano foi chamado de limens o espaço que ficava nos confins entre as terras do Império e a dos povos chamados bárbaros. Estes limites eram marcados por um objeto, um pórtico ou uma pedra. Em nosso caso, não é uma pedra ou qualquer outro objeto, temos um poeta liminal. A sua poética habita esta fronteira e ela nos desperta porque sonha com a inauguração do espaço feliz. A poesia, neste caso, converte a esperança em docta spes. Como disse muito bem o filósofo da Poética do espaço: "Com a poesia a imaginação coloca-se na margem em que precisamente a função do irreal vem arrebatar ou inquietar - sempre despertar - o ser adormecido nos seus automatismos" (BACHELARD, 1998, p. 18).

As palavras certeiras, proféticas e poéticas de Casaldáliga, passaram a ser veiculadas pela imprensa religiosa católica, em um projeto editorial popular, que difundiu o lirismo libertador de Casaldáliga para os lares católicos brasileiros por meio da Revista Ave Maria. Além disso, um passo a mais foi dado para mostrar que tanto na revista quanto na própria Prelazia de São Félix a arte poética de Casaldáliga estava intimamente ligada à expressão artística do pintor Mino Cerezo Barredo. Assim, temos duas pessoas que no contexto latino-Americano podem ser consideradas pessoas de fronteiras que realizam um gesto por meio da poesia e dos murais que convidam a superar as divisões. Outro passo foi o de descobrir outro profeta habitante dos limens que foi o teólogo luterano Vítor Westhelle. Eles nos fizeram pensar numa escatologia espacial-martirial como chave de leitura do sentido da vida, das lutas sociais, da teologia e da arte latino-americana. Westhelle auxilia a interpretação das poesias de Casaldáliga e das ilustrações de Cerezo como lugares para se sonhar espaços outros, geradores de encontros e profecias.

\section{Referências}

BACHELARD, Gaston. A Poética do Espaço. São Paulo: Martins Fontes, 1998.

BOFF, Leonardo. Uma revolução espiritual. in CASALDÁLIGA, Pedro.; CEREZO BARREDO, Maximino. Murais da libertação na Prelazia de São Felix do Araguaia, MT, Brasil. São Paulo: Loyola, 2005, p. 7-8.

CASAldÁliga, PEDro. Biografia de Cerezo Barredo. in BARREDo, Cerezo; CASALDÁligA, Pedro. Murais da libertação na Prelazia de São Félix do Araguaia, MT, Brasil. São Paulo: Loyola, 2005, p. 75-78.

CASAldáligA, Pedro. Com Deus no meio do povo. São Paulo: Paulinas, 1985.

CASAldáligA, Pedro. Martírio do Pe. João Bosco Penido Burnier. São Paulo: Loyola, 2006. 
CASAldÁligA, Pedro. Memória e compromisso. in CASAldÁligA, Pedro; TIERRA, Pedro; COPLAS, Martin. Missa da Terra sem Males. Rio de Janeiro: Tempo e Presença, 1980, p. 9-19.

CASALDÁligA, Pedro. Na procura do Reino: antologia de textos, 1968-1988. São Paulo: FTD, 1988.

CEREZO BARREDO, Maximino. La eucaristía en la obra artística de Maximino Cerezo Barredo. in AA.VV. Danos hoy nuestro pan de cada día. Simposio Eucaristía-Vida. Segovia: Missioneros Claretianos, 2015, p. 281-316.

CEREZO BARREDO, Maximino. Pedro, inspirador e guia. in AA.VV. Pedro Casaldáliga: as causas que imprimem sentido à sua vida - Retrato de uma personalidade. São Paulo: AveMaria, 2008, p. 341-358.

CONCÍLIO VATICANO II. Constituição dogmática Lumen gentium. 21 de novembro de 1964. Disponível em: <http://www.vatican.va/archive/hist_councils/ii_vatican_council/documents/ vat-ii_const_19641121_lumen-gentium_po.html>. Acesso 02 nov. 2020.

DIAS, Arcelina Helena Públio. Memória e libertação: caminhos do povo e os murais da prelazia de São Félix do Araguaia. São Paulo: Editora Ave-Maria, 2014.

FALECIMENTO Prof. Dr. Vítor Westhelle. Notícias. Faculdades EST. 2018. Disponível em: http://www.est.edu.br/noticias/visualiza/falecimento-prof--dr--vitor-westhelle. Acesso 03 nov. 2020.

FAVRE, Sara. Un viaggio latino-americano. Maximino Cerezo Barredo: uomo, artista, missionario. Udine: Forum, 2012.

FERNANDES, Marcio Luiz. A arte mural de Mino Cerezo Barredo no período militar brasileiro. Revista Caminhando, v. 25, n. 2, p. 185-200, 2020.

FOUCAULT, Michel. De espaços outros. Estudos Avançados, v. 27, n. 79, p. 113-122, 2013.

GONÇALVES, Marcos. Missionários da 'boa imprensa': a revista Ave Maria e os desafios da imprensa católica nos primeiros anos do século XX. Revista Brasileira de História. São Paulo, v. 28, n 55, p. 63-84, 2008.

MARZEC, Zofia. Pedro, poeta. in AA.VV. Pedro Casaldáliga: as causas que imprimem sentido à sua vida - Retrato de uma personalidade. São Paulo: Ave-Maria, 2008, p. 275-305.

MENDONZA-ÁLVAREZ, Carlos. O Deus escondido da pós-modernidade: desejo, memória e imaginação escatológica. Ensaio de teologia fundamental pós-moderna. São Paulo: É Realizações, 2011.

MOLTMANN, Jürgen. O caminho de Jesus Cristo: cristologia em dimensões messiânicas. São Paulo: Editora Academia Cristã, 2009.

MOLTMANN, Jürgen. The crucified God: the cross of Christ as the foundation and criticism of Christian theology. Minneapolis: Fortress Press, 1993.

RICOEUR, Paul. "O bom uso das feridas da memória”. 2002. Textos Traduzidos de Paul Ricoeur. Instituto de Estudos Filosóficos. Universidade de Coimbra. Disponível em: https://www. uc.pt/fluc/uidief/textos_ricoeur/o_bom_uso_das_feridas_da_memoria. Acesso: 22 mai. 2020.

SAFRA, Gilberto. Hermenêutica na situação clínica: o desvelar da singularidade pelo idioma pessoal. São Paulo: Edições Sobornost, 2006. 
SEQUERI, PierAngelo. Estetica e Teologia. L'indicibile emozione del Sacro: R. Otto, A. Schonberg, M. Heidegger. Milano: Glossa, 1993.

SOBRINO, Jon. Jesus na América Latina: seu significado para a fé e a cristologia. São Paulo: Vozes-Loyola, 1985.

SOUZA, Marinete Luzia Francisca de. Entrevista com o pintor espanhol Maximino Cerezo Barredo. Revista Panorâmica, v. 27, p. 195-199, 2019.

TAMAYO, Juan José. La teología de la liberación: en el nuevo escenario político y religioso. Valencia: Tirant lo blanch, 2011.

TAMAYO, Juan José. Entre la poesía, la mística y la revolución. Religión Digital. 08 ago. 2020. Disponível em: https://www.religiondigital.org/el_blog_de_juan_jose_tamayo/ Juan-Jose-Tamayo-internacional-revolucion-muerte-pedro-casaldaliga-obispo-pobres-misticopoeta_7_2257344254.html. Acesso: 10 out. 2020.

TIERRA, Pedro. Um par de sandálias para o peregrino. [1974]. "Pedro Passagem", mensagem de Pedro Tierra a Casaldáliga. 08 ago. 2020. Fundação Perseu Abramo. Disponível em: https://fpabramo.org.br/2020/08/08/pedro-passagem-mensagem-de-pedrotierra-a-casaldaliga/. Acesso 12 out. 2020.

VALÉRIO, Escorsi Mairon. Entre a cruz e a foice: D. Pedro Casaldáliga e a significação religiosa do Araguaia. São Paulo: USP, 2007. Dissertação (Mestrado na área de concentração de História Cultural), Universidade de Campinas, 2007.

VILLAS BOAS, Alex. Teologia e poesia: a busca de sentido em meio às paixões em Carlos Drummon de Andrade como possibilidade de um pensamento poético teológico. Sorocaba: Crearte, 2011.

WESTHELLE, Vítor. Eschatology and space: the lost dimension in theology - past and present. New York: Palgrave Macmillan, 2012.

WESTHELLE, Vítor. O Deus escandaloso: o uso e abuso da cruz. São Leopoldo: Sinodal/ EST, 2008.

WESTHELLE, Vítor. O evento igreja: chamado e desafio a uma igreja protestante. São Leopoldo: Sinodal/EST, 2017.

ZEFERINO, Jefferson; FERNANDES, Marcio Luiz. O sofrimento dá o que pensar: teologia pública em diálogo com a literatura marginal. Teoliterária, v. 10, n. 21, p. 470-497, 2020.

ZWETSCH, Roberto. Apresentação. in WESTHELLE, Vítor. Através do tempo e do espaço: reflexões de uma teologia luterana de alma latino-americana. São Leopoldo: EST, 2018, p. 7-13.

ZWETSCH, Roberto. Wind, Breeze, Hurricane. On poetry and theology - insights from the perspective of Brazilian literature. in PHILLIP, Mary; NUNES, John Arthur; COLLIER, Charles M. Churrasco: a theological feast in honor of Vitor Westhelle. Eugene: Wipf \& Stock, 2013, p. 82-93.

Submetido em: 15-10-2020

Aceito em: 27-11-2020 